\title{
Philonthus hepaticus (Coleoptera, Staphylinidae) in eastern Canada: are distribution gaps distinctive features or collecting artifacts?
}

\author{
Christopher G. Majka', Jean-Philippe Michaud², Gaétan Moreau², Aleš Smetana \\ I Research Associate, Nova Scotia Museum, 1747 Summer Street, Halifax, Nova Scotia, Canada 2 Université \\ de Moncton, Département de Biologie, Pavillon Rémi-Rossignol, Moncton, New Brunswick, Canada 3 Agri- \\ culture and Agri-food Canada, K. W. Neatby Bldg., Ottawa, Ontario, Canada \\ Corresponding author: Christopher G. Majka (c.majka@ns.sympatico.ca)
}

Academic editor: Jan Klimaszewski | Received 27 May 2009 | Accepted 30 June 2009 | Published 28 September 2009

Citation: Majka CG, Michaud J-P, Moreau G, Smetana A (2009) Philonthus hepaticus (Coleoptera, Staphylinidae) in eastern Canada: are distribution gaps distinctive features or collecting artifacts? In: Majka CG, Klimaszewski J (Eds) Biodiversity, Biosystematics, and Ecology of Canadian Coleoptera II. ZooKeys 22: 347-354. doi: $10.3897 /$ zookeys.22.208

\begin{abstract}
Philonthus hepaticus Erichson is reported for the first time in eastern Canada, and for only the second time in Canada, from a specimen collected in New Brunswick. This discovery provides an opportunity to examine apparent distribution gaps in the range of some rove beetles found in the Maritime Provinces of Canada. Some of these gaps may be due to deficiencies in collecting effort, while others may result from historic and prehistoric dispersal pathways, habitat fragmentation, or physiographic or climatic factors that allow species to exist in areas beyond their primary geographic range.
\end{abstract}

\section{Keywords}

Coleoptera, Canada, New Brunswick, Staphylinidae, Staphylininae, Philonthus, range extensions, distribution gaps

\section{Introduction}

The zoogeography of the Staphylinidae in Atlantic Canada is still imperfectly known, and knowledge of this speciose family in the region is still actively developing. Some Atlantic Canadian species exhibit striking apparent gaps in distribution. The Aleochari- 
nae are the most poorly known subfamily of the Staphylinidae, and as Majka and Klimaszewski (2008) pointed out, the confused and poorly understood systematics and taxonomy of the group, their small size, the specialized microhabitats they inhabit, and the external similarity of many species, have meant that they have been largely ignored in many faunistic, zoogeographic, ecological, and taxonomic studies. Majka and Klimaszewski (2008) provided 94 new provincial and state records of 53 species of North American aleocharines, which included many significant range extensions. Consequently, apparent distribution gaps in the range of most aleocharines may simply be an artifact of collecting effort, or the lack of taxonomic resources to identify specimens.

However, even amongst the Staphylininae, arguably the best-known subfamily of rove beetles in North America, there are Atlantic Canadian species that exhibit significant distribution gaps. Some examples include Acylophorus caseyi Leng, which is known from Halifax and Waverley, Nova Scotia, and is otherwise recorded in eastern Massachusetts (a distribution gap of $685 \mathrm{~km}$ ); Hemiquedius ferox (LeConte), which is known from Halifax and Crescent Beach, Nova Scotia, and is otherwise recorded in Paris, Maine (550 km); Quedius spelaeus spelaeus Horn, which is known from several sites in Hants County, Nova Scotia, and is otherwise recorded from Sullivan County, New York, (950 $\mathrm{km}$ ) (Smetana 1965, 1971) (Fig. 1); Gabrius ulpius Smetana, which is known from the Aspy River, Nova Scotia, and is otherwise recorded from Gorham, New Hampshire (860 km); Philonthus rufulus Horn, which is known from Sable Island, Nova Scotia and is otherwise recorded from southwestern Maine $(880 \mathrm{~km})$; and Philonthus thoracicus (Gravenhorst), which is known from Kouchibouguac National Park, New Brunswick, and is otherwise recorded in Paris, Maine (510 km) (Smetana 1995) (Fig. 2).

\section{Results}

In the present paper we add a further species to this roster, Philonthus hepaticus Erichson, 1840, on the basis of a specimen collected in Bouctouche, Kent County, New

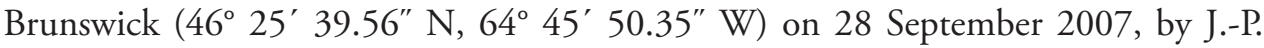
Michaud. The specimen was recovered on a domestic pig (Sus scrofa Linnaeus) carcass that had decomposed for 22 days in an agricultural field. For a comprehensive description of field characteristics and of the methods used to collect specimens, see Michaud and Moreau (2009). This represents the first record of this species in eastern Canada, and only the second Canadian record. The single previous Canadian record was a specimen collected in Vancouver, British Columbia, 3 August 1956 by B.F. and J.L. Carr (Smetana 1995).

\section{Discussion}

In terms of the bionomics of the species, Smetana (1995: 179) wrote that, "Philonthus hepaticus occurs in various kinds of rotting organic matter, such as dung (particularly 


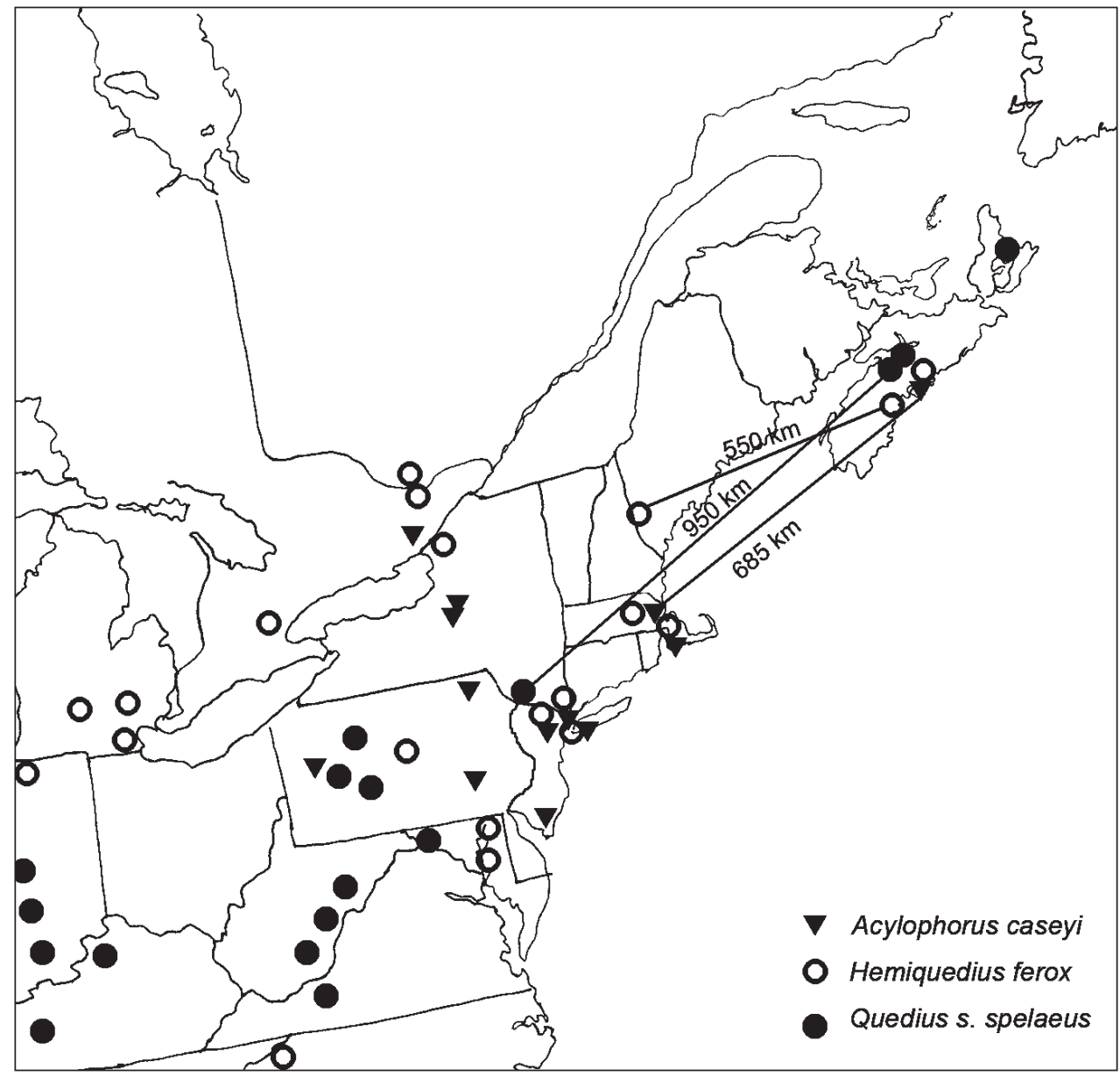

Figure I. Distribution of Acylophorus caseyi, Hemiquedius ferox, and Quedius s. spelaeus in northeastern North America [derived from Smetana (1971) and Moseley et al. (2006)].

horse and cow dung), rotting and fermenting fruit and vegetables, compost piles, grass cuttings, etc. Specimens were also taken by sifting litter and other forest floor debris, in seaweed and other beach debris and from litter along streams...."

In general, $P$. hepaticus occurs across the United States from Massachusetts to northern California, on an arc roughly south of $41^{\circ} \mathrm{N}$ latitude, south to the states of Puebla and Veracruz in southern Mexico ( $19^{\circ} \mathrm{N}$ latitude). Consequently its discovery in eastern New Brunswick, approximately $680 \mathrm{~km}$ north of central Massachusetts where it has been previously recorded (Smetana 1995) is noteworthy (Fig. 3). This initial record should be followed by further research to determine the extent of this species' distribution in the province.

Philonthus hepaticus is a fully macropterous species capable of flight. Smetana (1995) noted that flight ability in the Philonthina is best developed in species that 


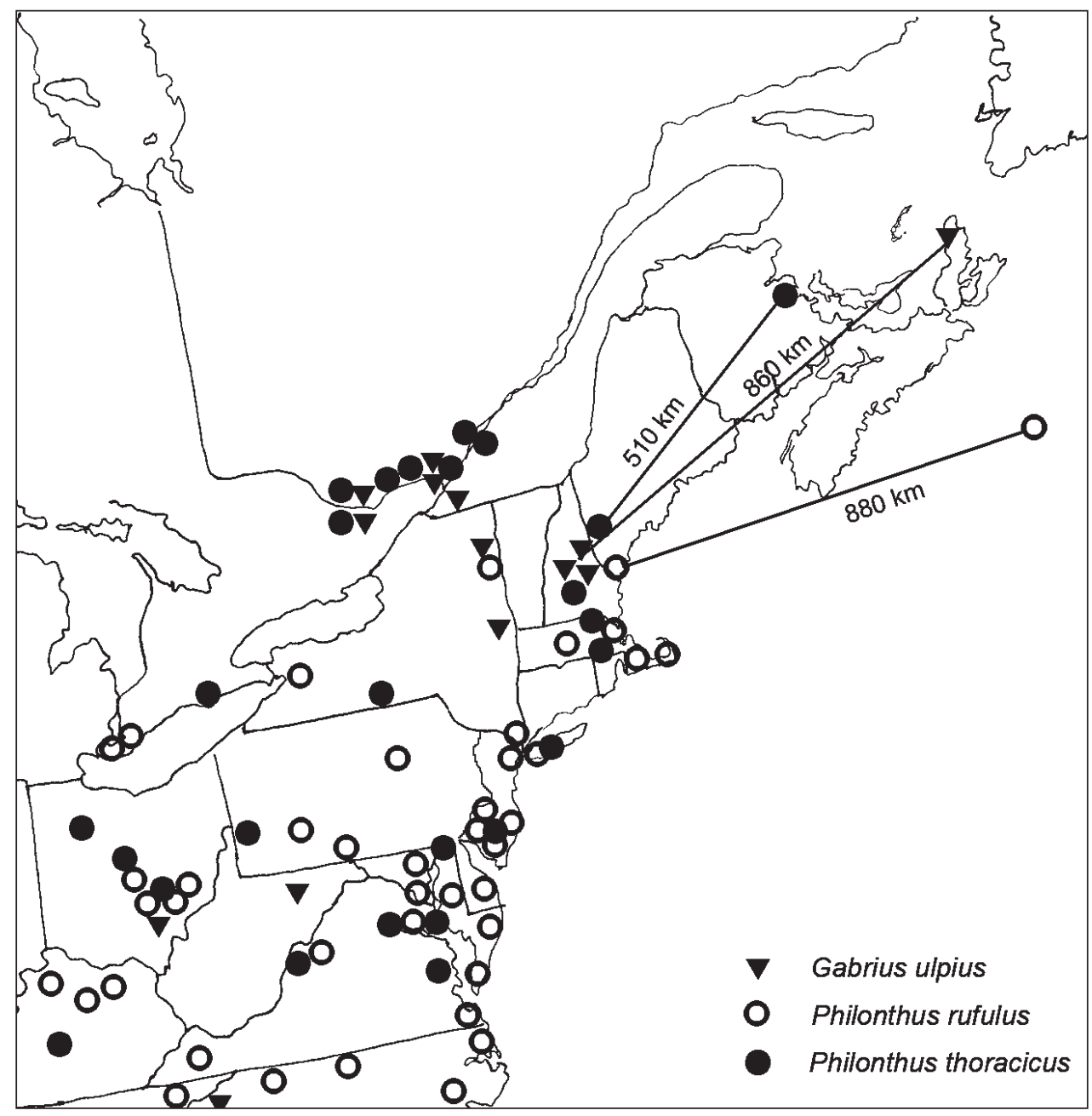

Figure 2. Distribution of Gabrius ulpius, Philonthus rufulus, and Philonthus thoracicus in northeastern North America (derived from Smetana 1995).

are predaceous on insects and their larvae (particularly Diptera), which are found in decompositional environments. Such species have sensitive olfactory chemoreceptors for detecting byproducts of decomposition, and fly quickly and readily in search of food. They are also ready crepuscular dispersers, and their highly developed flying ability has (in part) been instrumental in the vast ranges exhibited by many species of Philonthus. All this is likely to be true of $P$. hepaticus; however, it is also the case that with the exception of a couple of records (from British Columbia and Montana) the entire range of this species lies south of $41^{\circ} \mathrm{N}$ latitude, apparently indicating that despite the apparent dispersal abilities of this species, climatic, physiographic, ecological or other factors have limited the nothward extend of its distribution. In this regard it is noteworthy that the Northumberland Coastal Plain of the Atlantic Maritime Ecozone 


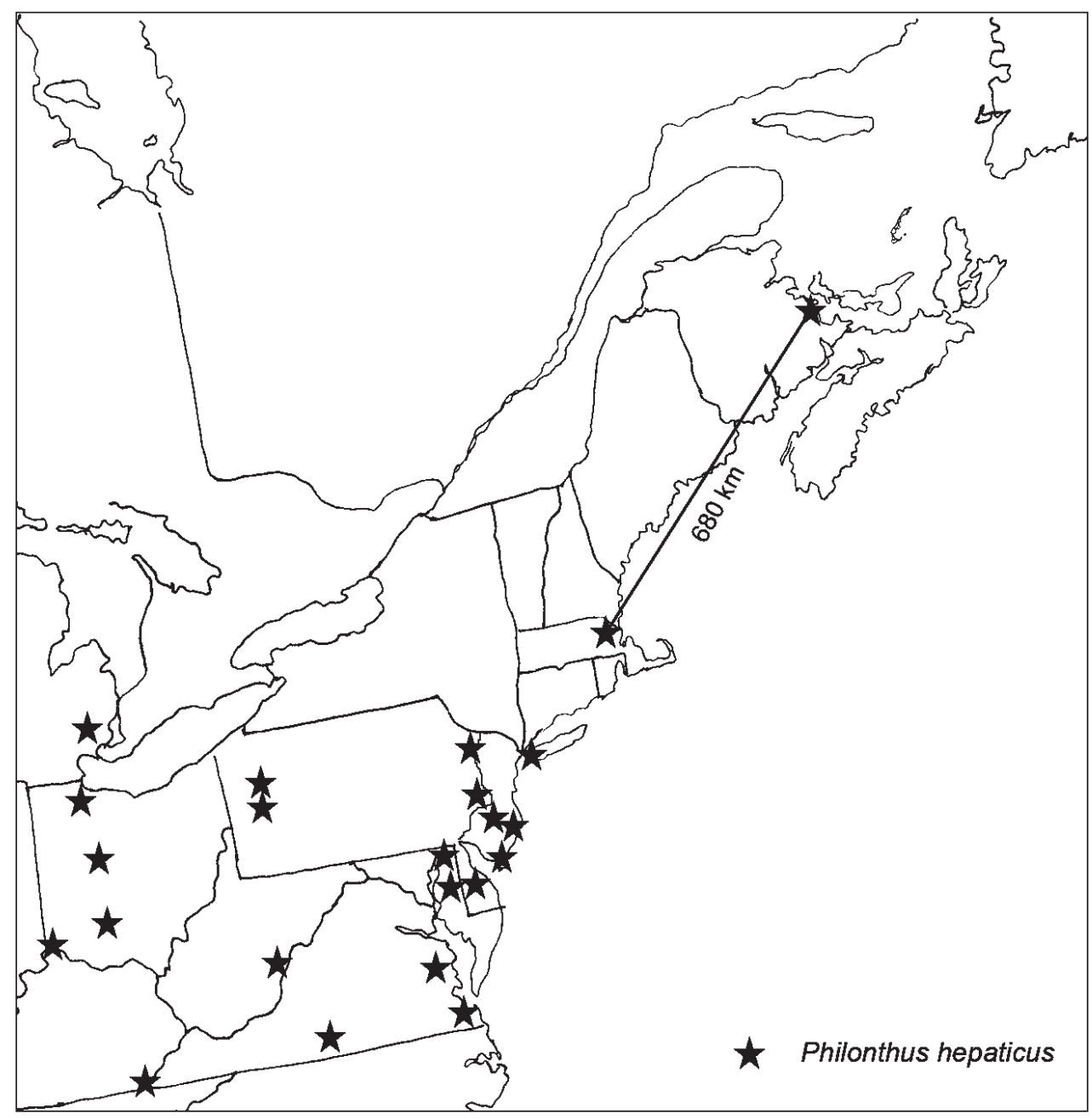

Figure 3. Distribution of Philonthus hepaticus in northeastern North America (derived from Smetana 1995).

(where Bouctouche is situated) has the highest mean summer temperatures (together with isolated small pockets elsewhere), averaging $+19^{\circ} \mathrm{C}$ (1951-1980 values) of any region in Atlantic Canada (McCalla 1988). Perhaps this is a contributing factor that allows $P$. hepaticus to survive in this area.

Philonthus hepaticus has in common with the rove beetles listed above, a distribution that apparently stops in central or northern New England, and then resumes in the Maritime Provinces of Canada. In some instances, this distribution pattern may be an artifact of collecting history, but in the case of some species such as Q. s. spelaeus (Moseley et al. 2006) and P. rufulus, these distribution gaps appear to reflect genuine disjunctions and indicate populations isolated from the balance of the range of the species. There are many examples of such species amongst other families of Coleoptera. A 


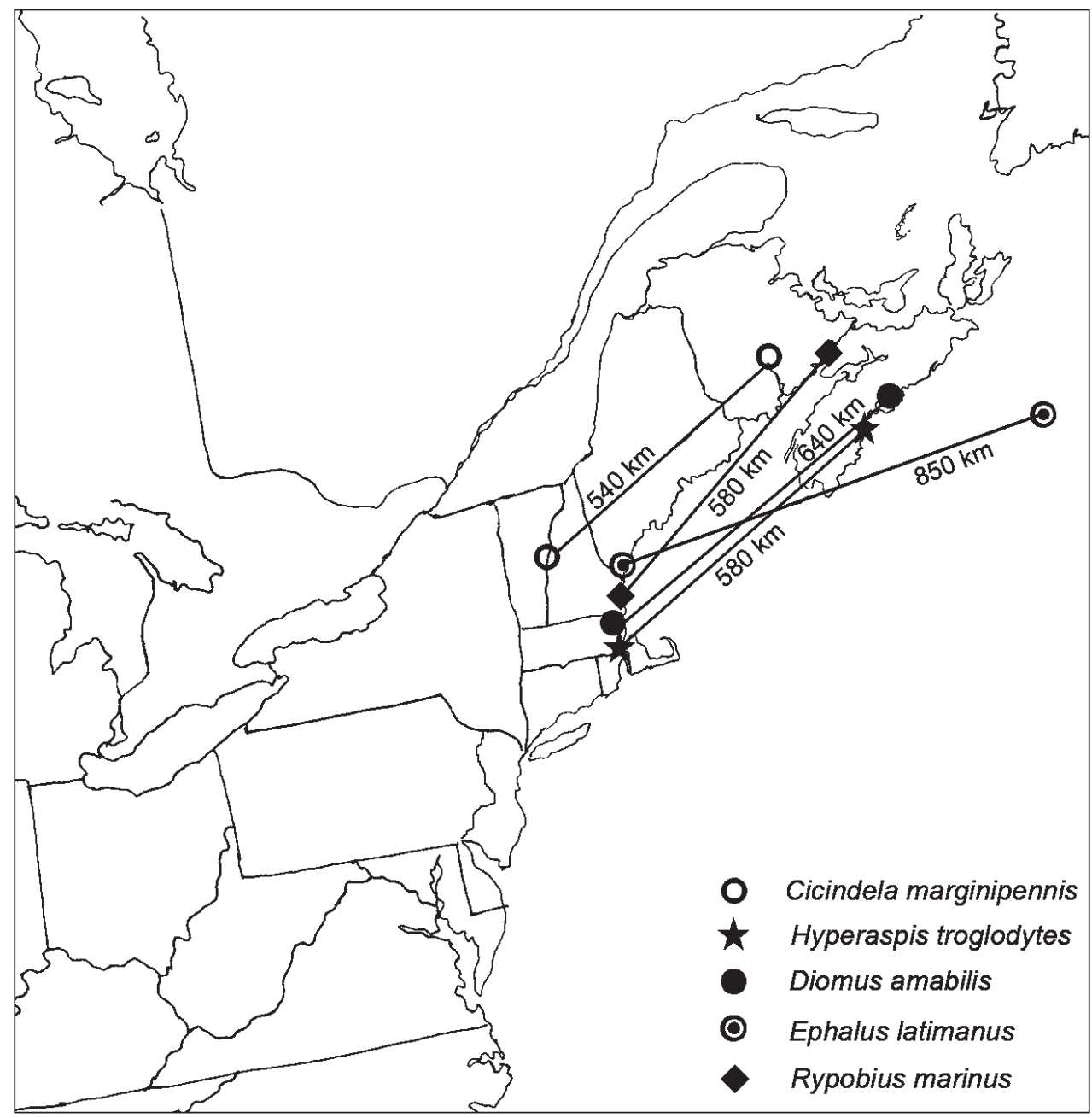

Figure 4. Nearest populations to Atlantic Canada of Cicindela marginipennis, Hyperaspis troglodytes, Diomus amabilis, Ephalus latimanus, and Rypobius marinus (derived from Leonard and Bell 1999; Majka et al. 2008; Majka and Cline 2006; Majka and McCorquodale 2006; Sabine 2004).

few that illustrate the pattern include Diomus amabilis (LeConte), and Hyperaspis troglodytes Mulsant [Coccinellidae] (Majka and McCorquodale 2006); Ephalus latimanus (LeConte) [Tenebrionidae] (Majka et al. 2008); Rypobius marinus LeConte [Corylophidae] (Majka and Cline 2006), and Cicindela marginipennis Dejean [Carabidae] (Sabine 2004) (Fig. 4).

Majka and McCorquodale (2006) pointed out that some disjunct distributions in this region are similar to those of the coastal plain element of the Nova Scotian flora, plants which are found north to New England in the United States, whose distribution then resumes in southern Nova Scotia. Keddy and Wisheu (1989) proposed that the coastal plain flora arrived in southern Nova Scotia after the Wisconsinian glaciation by 
migrating across Georges Bank to Browns Bank and thence to the mainland of the province. Klimaszewski et al. (2006) discussed the role of offshore glacial refugia like Georges Bank, and post-glacial island networks in the invertebrate colonization of Sable Island. It is possible that some roves beetles with such disjunct distributions could have dispersed to the Maritime Provinces via this pathway, accounting for such observed distribution patterns. Others may have dispersed to the region via continental pathways, and have subsequently been isolated from the balance of their respective ranges by changing environmental circumstances. Still others may not be disjunct at all (see below).

Are such disjunct distribution patterns real, or are they simply an artifact of collection effort? Only further research will resolve these questions. In particular, biodiversity research on Coleoptera in the state of Maine, a key area in discerning the faunistic relationships between New England and Atlantic Canada, has been fragmentary to date. Some of these distribution gaps (i.e., for species such as Quedius s. spelaeus, Philonthus rufulus, Ephalus latimanus, and Cicindela marginipennis) are clearly not simply artifacts of collecting effort. They may be a result of a variety of factors including historic and prehistoric dispersal pathways, habitat fragmentation, and physiographic or climatic factors that allow species to exist in areas beyond their primary geographic range. Although many questions remain to be answered, such preliminary findings point the way for profitable future biodiversity and zoogeographic research.

\section{Acknowledgements}

We thank Calum Ewing and Andrew Hebda for their assistance, and NSERC for funding the fieldwork.

\section{References}

Keddy PA, Wisheu IC (1989) Ecology, biogeography, and conservation of coastal plain plants: some general principles from the study of Nova Scotian wetlands. Rhodora 91: 72-94.

Klimaszewski J, Majka CG (2007) Euvira micmac, a new species (Coleoptera: Staphylinidae: Aleocharinae), and first record of the genus in Canada. The Canadian Entomologist 139: 147-153.

Klimaszewski J, Majka CG, Langor D (2006) Review of the North American Tarphiota Casey, with a description of a new seashore-inhabiting species Atheta species exhibiting convergent characteristics (Coleoptera: Staphylinidae: Aleocharinae). Entomological Science 9: 67-78.

Leonard JC, Bell RT (1999) Northeastern Tiger Beetles: A field guide to Tiger Beetles of New England and Eastern Canada. CRC Press, Boca Raton, Florida, 175 pp.

Majka CG, Bouchard P, Bousquet Y (2008) The Tenebrionidae (Coleoptera) of the Maritime Provinces of Canada. The Canadian Entomologist 140: 690-713.

Majka CG, Cline AR (2006) New Records of Corylophidae (Coleoptera) from the Maritime Provinces of Canada. The Coleopterists Bulletin 60(2): 105-111. 
Majka CG, Klimaszewski J (2008) New records of Canadian Aleocharinae. Biodiversity, Biosystematics, and Ecology of Canadian Coleoptera. In: Majka CG, Klimaszewski J (Eds) Biodiversity, Biosystematics, and Ecology of Canadian Coleoptera. ZooKeys 2: 85-114. http:// pensoftonline.net/zookeys/index.php/journal/article/view/7/20 [accessed 27.V.2009]

Majka CG, McCorquodale DB (2006) The Coccinellidae (Coleoptera) of the Maritime Provinces of Canada: new records, biogeographic notes, and conservation concerns. Zootaxa 1154: 49-68. http://www.mapress.com/zootaxa/2006f/zt01154p068.pdf [accessed 27.V.2009]

McCalla RJ (1988) The Maritime Provinces Atlas. Maritext, Halifax, Nova Scotia, 96 pp.

Michaud J-P, Moreau G (2009) Predicting the visitation of carcasses by carrion-related insects under different rates of degree-day accumulation. Forensic Science International 185: 78-83.

Moseley M, Klimaszewski J, Majka CG (2006) Description of the pupa and observations on the distribution, ecology and life history of Quedius spelaeus spelaeus Horn (Coleoptera: Staphylinidae) in Nova Scotia, Canada. Zootaxa 1226: 61-68.

Sabine DL (2004) First record of Cicindela marginipennis Dejean from Canada. Cicindela 36(3-4): 53-56.

Smetana A (1965) Staphylinini und Quediini (Col., Staphylinidae) von Newfoundland, Südost-Labrador und Nova Scotia. Acta Entomologica Fennica 20: 1-60.

Smetana A (1971) Revision of the tribe Quediini of America north of Mexico (Coleoptera: Staphylinidae). Memoirs of the Entomological Society of Canada 79: 1-303.

Smetana A (1995) Rove beetles of the subtribe Philonthina of America north of Mexico (Coleoptera: Staphylinidae) classification, phylogeny and taxonomic revision. Memoirs on Entomology International 3: i-x, 1-946. 